\title{
Silica decouples fungal growth and litter decomposition without changing responses to climate warming and $\mathrm{N}$ enrichment
}

\author{
Jörg Schaller,${ }^{1,7}$ Jessica Hines,,${ }^{2,3}$ Carsten Brackhage, ${ }^{1}$ Ernst Bäucker,${ }^{4}$ and Mark O. Gessner ${ }^{2,3,5,6}$ \\ ${ }^{1}$ Institute of General Ecology and Environmental Protection, Technische Universität Dresden, PF 1117, 01737 Tharandt, Germany \\ ${ }^{2}$ Department of Aquatic Ecology, Eawag: Swiss Federal Institute of Aquatic Science and Technology, Überlandstrasse 133, \\ 8600 Dübendorf, Switzerland \\ ${ }^{3}$ Department of Experimental Limnology, Leibniz Institute of Freshwater Ecology and Inland Fisheries (IGB), Alte Fischerhütte 2, \\ 16775 Stechlin, Germany \\ ${ }^{4}$ Institute of Forest Utilization and Forest Technology, Technische Universität Dresden, 01737 Tharandt, Germany \\ ${ }^{5}$ Institute of Integrative Biology (IBZ), ETH Zurich, Universitätstrasse 16, 8092 Zurich, Switzerland \\ ${ }^{6}$ Department of Ecology, Berlin Institute of Technology (TU Berlin), Ernst-Reuter-Platz 1, 10587 Berlin, Germany
}

Abstract. Ongoing global changes, such as climate warming and increasing supply of reactive nitrogen $(\mathrm{N})$, are expected to affect essential ecosystem processes such as the decomposition of plant litter. Determining the influence of environmental heterogeneity on the magnitude of these effects remains an important task, with silicon $(\mathrm{Si})$ availability being a notable component of this heterogeneity, especially for grasses. We conducted an outdoor enclosure experiment to test if increased Si supply to a widespread foundation species (Phragmites australis) alters the effect of climate warming and excess $\mathrm{N}$ supply on litter decomposition by curbing fungal decomposers. Consistent with expectations, $\mathrm{Si}$ supply during plant growth reduced fungal biomass in decomposing leaf blades by $50 \%$, an effect that was doubled by excess external $\mathrm{N}$ supply. These strong impacts, however, did not directly translate to reduced litter decomposition or associated changes in nutrient dynamics. Instead, plant tissue-specific effects determined the influence of $\mathrm{Si}, \mathrm{N}$, and elevated temperature on litter mass loss. Specifically, Si accelerated the decomposition of leaf sheaths, warming enhanced leafsheath and leaf-blade decomposition, and $\mathrm{N}$ decreased the decomposition of culm litter, in line with expectations based on differences in litter chemistry. Thus, despite highly detrimental effects of Si and $\mathrm{N}$ on fungal decomposers, compensation by other members of the microbial community could dampen the realized impact of these global-change factors on the decomposition of plant litter in the future.

Key words: ecosystem processes; experimental warming; fungal biomass; global change; mesocosm; nitrogen deposition; Phragmites australis; silica cycle.

\section{INTRODUCTION}

Multiple factors of global change are simultaneously confronting ecosystems worldwide. Although model predictions vary in magnitude, warming trends observed in the recent past are consistently projected to continue in the future (IPCC 2007, Blunden et al. 2011), leading to rising temperatures not only in the atmosphere and oceans but also in inland waters such as lakes, rivers and wetlands (Adrian et al. 2009, Jeppesen et al. 2010). Anthropogenic activities are also altering the global availability of several biologically important elements. Best known is the massive conversion of atmospheric molecular nitrogen $\left(\mathrm{N}_{2}\right)$ to biologically available forms, mainly as a result of industrial processes and growth of nitrogen-fixing leguminous plants in agriculture (Galloway et al. 2008). This has doubled the natural global $\mathrm{N}$

Manuscript received 12 November 2013; revised 3 April 2014; accepted 8 May 2014. Corresponding Editor: P. H. Templer.

${ }^{7}$ E-mail: Joerg.Schaller@tu-dresden.de fixation rate, resulting in widespread increases in $\mathrm{N}$ loading of surface waters (Vörösmarty et al. 2010), sometimes altering species distributions, food web interactions, and rates of biogeochemical cycling, which has marked consequences for the structure and functioning of aquatic ecosystems (Jeppesen et al. 2010).

An accumulation of evidence suggests that climate warming and nitrogen deposition will also impact the decomposition of plant litter, an essential ecosystem process in terrestrial, wetland, and many aquatic ecosystems. Warming tends to accelerate decomposition, whereas increases in external nitrogen supply can accelerate or retard decomposition, depending on litter chemistry (Knorr et al. 2005, Hobbie et al. 2012). However, the magnitude of global change effects on ecosystem processes will not be uniform across all environments. An intrinsic feature of ecosystems is the spatial heterogeneity in the distribution of mineral resources available to primary producers. This heterogeneity occurs at multiple scales, including the landscape scale. As a result, plants have evolved a huge number of adaptations for tolerating, or capitalizing on, environ- 
mental heterogeneity. Determining how these adaptations at the plant and plant tissue level scale up to influence responses of ecosystems to global change remains an important task.

Silicon, the second most abundant constituent in the Earth's crust, is spatially distributed in a heterogeneous fashion and could play an important role in the sensitivity of decomposition to global environmental changes, such as climate warming and excess nitrogen deposition. In particular, ecosystems dominated by silicon-accumulating grasses typically cycle large amounts of silicon via mobilization, root uptake, and litter fall (Cornelis et al. 2010). Silicon also assumes special importance in the defense of plants, particularly against large ungulate herbivores (McNaughton and Tarrants 1983, McNaughton et al. 1985), herbivorous rodents (Soininen et al. 2013), and insects (Massey and Hartley 2009), and there is also evidence that silica in plants is effective against fungal infestation (Fauteux et al. 2005). Deterrent properties of Si are likely to remain effective after plant death. Therefore, increases in silica concentrations in plant tissues could impede fungal decomposers in ways similar to Si effects on live plant tissue utilization by fungal pathogens. By limiting growth of fungal decomposers, silicon accumulation in plants could dampen the impact of warming and nitrogen deposition on decomposition, as the impact of these global-change factors are manifest to a large extent through effects on microbial metabolism.

Responses of plants to environmental heterogeneity occur mainly at the level of individual plant tissues. That is, plant tissues (e.g., leaf blades, leaf sheaths, and stems) differ in their elemental composition and also in the extent to which those tissues are plastic in response to environmental heterogeneity. Consequently, the impact of global change on decomposition is likely to vary across individual plant tissues, either due to tissuespecific differences in $\mathrm{Si}$ content and plasticity in the tendency to accumulate $\mathrm{Si}$, or because silicon availability during plant growth modifies other aspects of tissue chemistry besides Si concentrations (e.g., C:N:P ratios, cellulose and phenol contents [Schaller et al. 2012a, $b$, 2013]). However, the magnitude of these effects and, in particular, their interactions with $\mathrm{N}$ availability and climate warming as forecast by climate-change scenarios, is virtually unknown at present. Si heterogeneity is likely to play an increasingly important role in ecosystem responses to global change in the future as natural weathering rates are altered (Struyf et al. 2010) and human population growth demands increased harvesting of Si-accumulating crops (Casey et al. 2004), thus changing Si mobilization and transport across landscapes and effectively resulting in heterogeneous $\mathrm{Si}$ deposition in wetlands and lakes (Struyf et al. 2010).

The present experiment was designed to test how variation in silicon availability affects the impact of climate warming and excess nitrogen supply on plant litter decomposition in a littoral freshwater marsh. We hypothesized that (1) warming will accelerate decomposition by stimulating microbial metabolism, and that (2) the impact of increased nitrogen supply on decomposition would depend on the recalcitrance of the plant litter. Importantly, we hypothesized that (3) by negatively affecting fungal decomposers, silicon will retard decomposition and dampen the effects of other factors of global change; and that 4) silica effects would be manifest at a plant-tissue-specific level with the strongest effect on decomposition occurring in the tissue with the highest initial silica content. By examining fungal biomass, nutrient immobilization, and decomposition, this study tested how plant responses to environmental heterogeneity in Si supply during plant growth could modify response of decomposition to two main factors of environmental change: climate warming and increased nitrogen deposition.

\section{Material and Methods}

\section{Study site}

The study was carried out in an outdoor climatechange facility located in a littoral marsh on the eastern shore of Lake Hallwil, Switzerland $\left(47^{\circ} 17^{\prime} 14.00^{\prime \prime} \mathrm{N}\right.$, $8^{\circ} 13^{\prime} 18.53^{\prime \prime} \mathrm{E}$ ), a eutrophic, postglacial, moraine lake with a surface area of $10.2 \mathrm{~km}^{2}$ and an average depth of $28.6 \mathrm{~m}$. Emergent wetland vegetation composed almost exclusively of Phragmites australis (Cav.) Trin. ex Steud. formed a band up to $20 \mathrm{~m}$ wide along portions of the shoreline. Maximum water depth at the lakeward marsh margin was about $1 \mathrm{~m}$. Water chemistry and other characteristics of the lake, its littoral Phragmites marsh, as well as the design and functioning of the facility, are given in Hines et al. (2013).

\section{Experimental design}

To determine the impact of warming, excessive external nitrogen supply, and litter silica concentration on decomposition, fungal biomass accrual, and nutrient immobilization in decomposing litter, we conducted a 2 $\times 2 \times 3$ factorial field experiment with a randomized complete block design. Treatment factors included two main factors of global change, warming and nitrogen addition (two levels each), in addition to three levels of silicon supplied to plants during growth. The simulated global-change factors applied to enclosures at the climate-change facility resulted in four treatments: controls (C) where water was kept at ambient temperature, warming $(\mathrm{H})$ where water temperature was raised above ambient by active heating (average of $2.03^{\circ} \mathrm{C}$ during the study period), enhanced nitrogen supply (N) achieved by monthly addition of dissolved $\mathrm{Ca}\left(\mathrm{NO}_{3}\right)_{2}$ to reach target concentrations about $5 \times$ above the ambient concentration, and warming and enhanced nitrogen supply in combination (HN; Appendix: Figs. A1 and A2). The targeted fivefold increase in $\mathrm{N}$ concentrations is consistent with increased nitrogen loads observed in northern temperate lakes (Elser et al. 2009) and the 
pulsed monthly additions simulated nitrogen delivery occurring during rain events (Hines et al. 2013). An unenclosed control plot (L) was also established to test for potential enclosure effects. Thus, five treatments were replicated in each of four random blocks, resulting in a total of 20 experimental units.

Each treatment was randomly assigned to an enclosure in the field facility that had been running continuously with minor interruptions since 2004, as described in detail by Hines et al. (2013). Briefly, each enclosure consisted of two nested polypropylene rings with an inner and outer diameter of 1.42 and $1.52 \mathrm{~m}$, respectively. Enclosures were pushed $20 \mathrm{~cm}$ into the sediment, resulting in a height of $1.2 \mathrm{~m}$ (Hines et al. 2013). They were open at the top and bottom and enclosed naturally grown shoots of $P$. australis. The total enclosure volume depended on the lake water level but was about $1 \mathrm{~m}^{3}$ at a water depth of $65 \mathrm{~cm}$. The silicon concentration in the lake and enclosure water ranged between 1 and $9 \mathrm{mg} / \mathrm{L}$ during the experiment, but did not differ among treatments.

Litter containing three different levels of silicon were obtained from a separate experiment where $P$. australis was grown in polyethylene pots $(15$ L) filled with purified water and $1 \mathrm{~kg}$ of peat containing $10 \% \mathrm{Si}$ by dry mass. The plants were exposed to silica treatments in a pot experiment that was separate from the global change enclosures. The pots with 10-25 Phragmites shoots each were placed in open-top chambers on land and supplied with filtered air. Twelve pots per treatment received one of three levels of low acidic $(\mathrm{pH} 4.7)$, amorphous Si (Aerosil 300; Evonik Industries AG, Essen, Germany): $0 \mathrm{~g}$ (Si-C), $10 \mathrm{~g}$ (Si-10), and $100 \mathrm{~g}$ silica (Si-100). Further details on growth conditions are given in Schaller et al. (2012b). Litter was harvested at the end of the growing season (19 November 2009) when shoots had turned brown. They were separated into leaf blades, leaf sheaths, and culms. Litter chemistry differed among the plant organs and Si treatments in terms of Si, $\mathrm{N}$, P, and slightly for cellulose and phenol content (Schaller et al. 2012a, b).

\section{Litter chemistry and mass loss}

The harvested fully brown leaf blades, sheaths, and culms were placed in separate litter bags $(20 \times 25 \mathrm{~cm})$ with a mesh size of $1 \mathrm{~mm}$. Each bag received $0.8-1.1 \mathrm{~g}$ of litter ash free dry mass (AFDM). There was insufficient sheath material to include a treatment in the unenclosed control plots (L), resulting in a total of 180 litter bags that were submerged in the enclosure facility in Lake Hallwil in early December 2009. Litter bags were retrieved after about $50 \%$ of the initial mass had been lost (checked by periodically sampling extra leaf bags); therefore, bags containing leaf blades and sheaths were retrieved in mid April 2010 after four months, those containing culms in December 2010 after exactly one year.
The litter was cleaned under flowing water, frozen at $-20^{\circ} \mathrm{C}$, and later freeze dried, ground to a particle size $<0.5 \mathrm{~mm}$ using a centrifugal mill (ZM 1000; Retsch, Hanau, Germany), and the leaf blades analyzed for carbon, nitrogen, phosphorus, and silicon using the same analytical methods described previously for undecomposed litter (Schaller et al. 2012a,b). Briefly, carbon and nitrogen contents were determined using an Elementar Vario EL III (Retsch) elemental analyzer (Deutsches Institut für Normung 1995). Litter for phosphorus analysis was digested in $3 \mathrm{~mL}$ of $\mathrm{HNO}_{3}{ }^{-}$ and $2 \mathrm{~mL}$ of $\mathrm{H}_{2} \mathrm{O}_{2}$ (Deutsches Institut für Normung 2002). For silicon analysis, ground litter was digested in a microwave digestion system (Mars5; CEM Corporation, Matthews, North Carolina, USA) in $3 \mathrm{~mL}$ of $\mathrm{HNO}_{3}, 1.5 \mathrm{~mL}$ of $\mathrm{HF}$, and $3 \mathrm{~mL}$ of $\mathrm{H}_{3} \mathrm{BO}_{3}$ (DIN-EN13805 2002). Standard reference material (poplar leaves, GBW7604; Office of Certified Reference Material, Langfang, China) was processed along with the samples. Silicon and phosphorus were determined by ICP-OES (Optima 7000DV; Perkin Elmer, Waltham, Massachusetts, USA) with UV detection and quantification at $251.6 \mathrm{~nm}(\mathrm{Si})$ and $213.6 \mathrm{~nm}(\mathrm{P})$. All chemicals were of analytical grade. To further examine the extent of silica deposition in plant tissue, leaf blades from plants grown under high Si supply (Si-100) were examined by scanning electron microscopy to determine carbon and silicon concentrations near the epidermis. Leaves of both undecomposed material and samples retrieved from the field were inspected. The microscope (JEOL T 330A; Röntec, Berlin, Germany) was equipped with an element detector (EDR 288; Röntec) and run at 15 $\mathrm{kV}$. Plant samples were critical-point dried and subsequently coated with gold (Zimmermann et al. 2000). An area of about $0.09 \mathrm{~mm}^{2}$ in the middle of selected leaf blades was scanned at a magnification of $350 \times$.

\section{Fungal biomass}

Ergosterol in leaf blades was determined as a measure of fungal biomass. Freeze-dried and ground leaf material $(50 \mathrm{mg})$ was extracted with $10 \mathrm{~mL}$ of $\mathrm{KOH} /$ methanol $(8 \mathrm{~g} / \mathrm{L} \mathrm{KOH})$ for 30 minutes at $80^{\circ} \mathrm{C}$ (Gessner and Schmitt 1996). Extracts were acidified with $2 \mathrm{~mL}$ of $0.65 \mathrm{~mol} / \mathrm{L} \mathrm{HCl}$ and loaded on solid-phase extraction cartridges (tC18; Waters No. WAT 043425; Waters Corporation, Milford, Massachusetts, USA). Cartridges were rinsed with a solution containing $22.4 \mathrm{~g} \mathrm{KOH}$ per liter of methanol/water (6:4 by volume) and dried for about an hour under a stream of air. Ergosterol was eluted with $1750 \mu \mathrm{L}$ of isopropanol (Gessner and Schmitt 1996). The resulting extracts were analyzed for ergosterol on a Jasco HPLC (Jasco, Gross-Umstadt, Germany) with methanol as the mobile phase (flow rate of $1.5 \mathrm{~mL} \mathrm{~min}^{-1}$ ) using a $250 \times 4 \mathrm{~mm}$ LichroSpher RP18 column (Merck No. 327799 ) maintained at $33^{\circ} \mathrm{C}$. Ergosterol was detected and quantified by measuring absorbance at $282 \mathrm{~nm}$. 

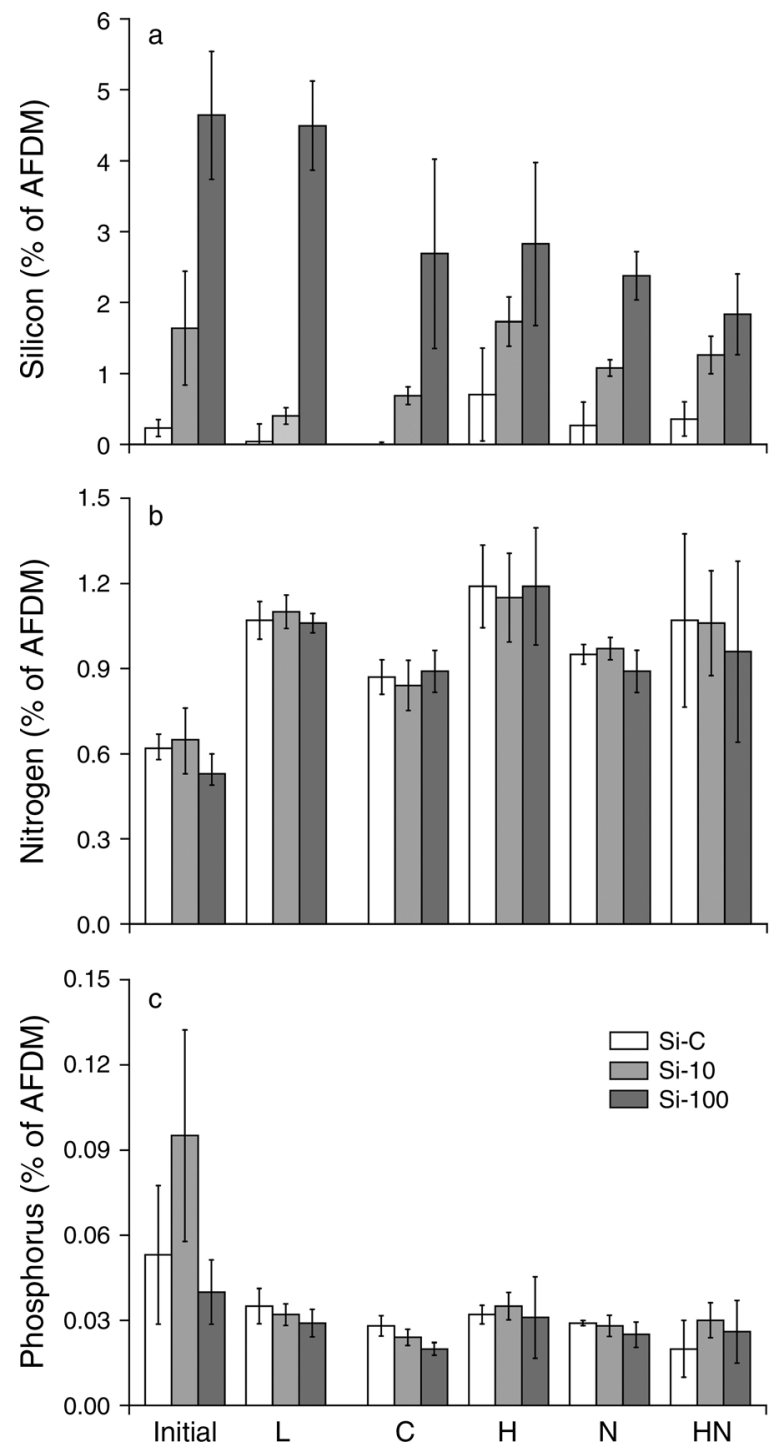

FIG. 1. (a) Silicon, (b) nitrogen, and (c) phosphorus concentrations (means $\pm \mathrm{SD}, n=4$ replicates) of Phragmites australis leaf blades at the beginning and end of a litter decomposition experiment in different environmental conditions: L, unenclosed control plot in a littoral marsh; C, untreated control enclosures; $\mathrm{H}$, heated enclosures; $\mathrm{N}$, enclosures receiving $\mathrm{NO}_{3}{ }^{-}$additions; and $\mathrm{HN}$, heated enclosures receiving $\mathrm{NO}_{3}{ }^{-}$additions. Initial denotes undecomposed litter, all other labels on the $x$-axis refers to litter retrieved in early April after four months of decomposition. Treatments are Si-C, no silicon fertilization; Si-10, $10 \mathrm{~g}$ silicon added per $10 \mathrm{~L}$ of substrate during plant growth; and $\mathrm{Si}-100,100 \mathrm{~g}$ silicon added per $10 \mathrm{~L}$ of substrate. AFDM stands for ash-free dry mass.

\section{Statistical analysis}

Separate three-way analyses of variance (ANOVA) were used to test for treatment effects on litter mass loss of leaf blades, leaf sheaths, and culms of $P$. australis. The factors included were warming (two levels), nitrogen addition (two levels), and silica during plant growth (three levels). The block factor was not significant and was therefore removed from the analysis. For leaf blades, we also assessed treatment effects on changes in litter chemistry occurring during decomposition (carbon, nitrogen, phosphorus and silicon concentrations), and fungal biomass measured as ergosterol content. To assess the potential for enclosures to affect results, we compared decomposition of all plant tissues in enclosed and unenclosed controls using two-way ANOVA with the presence of enclosures and $\mathrm{Si}$ availability during plant growth as categorical factors. All data met assumptions of homogeneity of variance and normal distribution of residuals. All statistical computations were performed with SPSS version 14.0 (IBM, Armonk, New York, USA).

\section{Results}

\section{Litter chemistry}

The initial concentrations of silicon in leaf blades differed 20-fold among plants supplied with varying amounts of Si during growth (Fig. 1a). Amorphous silica deposits initially present on the leaf surfaces of the plants receiving the highest Si concentrations had disappeared by the time of sampling after four months, and some of the silica bodies (phytoliths) appeared to have been partly dissolved by this time (Fig. 2). Nevertheless, differences in Si content among litter from plants grown under different Si supply regimes persisted in all cases (Fig. 1a), but did not influence other aspects of litter chemistry, either directly or interactively with other factors of global change (Fig. 1b, c, Appendix: Table A1). Nitrogen concentration in leaf litter consistently increased during decomposition, in some cases nearly doubling (Fig. 1b), whereas phosphorus concentrations decreased (Fig. 1c). These changes occurred across all treatments, independent of Si supply during plant growth. Warming and external nitrogen in combination enhanced the litter phosphorus concentration compared to the control litter (Table A1). The nitrogen concentration was not affected. However, warming enhanced the final concentrations of nitrogen in leaf litter, whereas external nitrogen supply had no influence (Fig. 1b, Table A1). Similarly, warming enhanced the final concentration of phosphorus, but only when no extra nitrogen was supplied (Fig. 1c), resulting in a significant interaction effect of warming and nitrogen supply on phosphorus (Table A1). Initial differences in the carbon content of plants exposed to different Si supply levels tended to diminish during decomposition, but were still apparent after four months, except in leaf litter retrieved from the heated enclosures (Fig. A3, Table A1).

\section{Fungal biomass}

The clearest and most consistent responses to altered $\mathrm{Si}$ supply and environmental conditions emerged for ergosterol, a measure of fungal biomass (Fig. 3). High silicon supplies during plant growth reduced ergosterol concentrations in leaf litter by about half compared to concentrations in litter from plants exposed to low and medium levels of $\mathrm{Si}(P=0.014$; Table A1). This effect was 
a) Leaf surface before decay

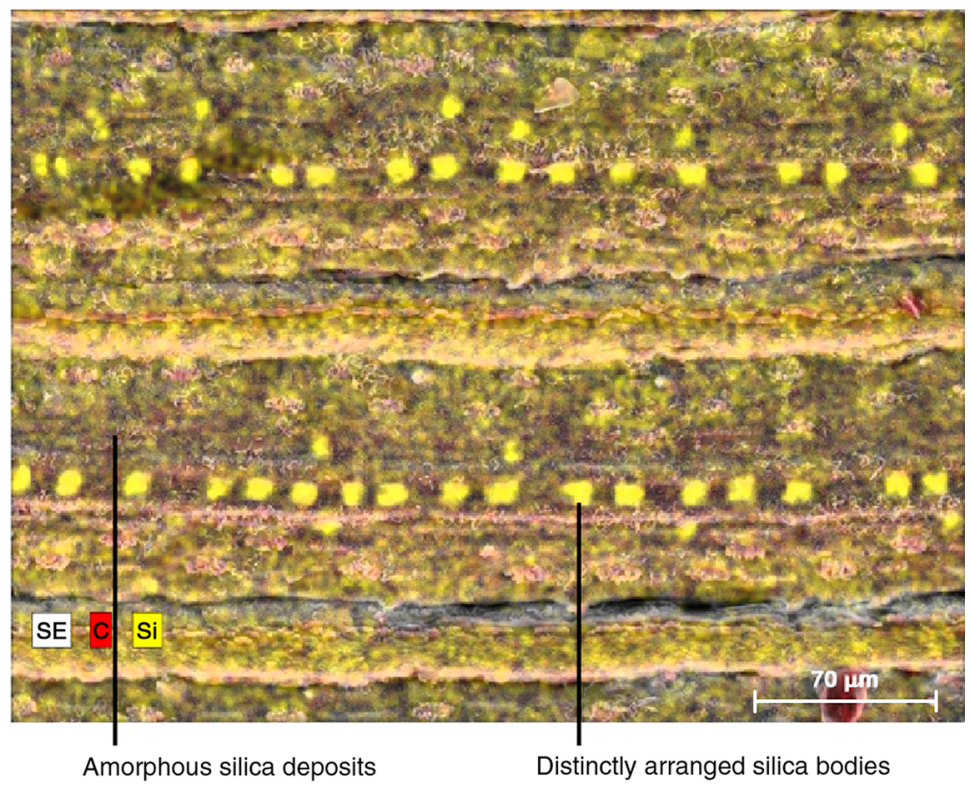

b) Leaf surface after decay

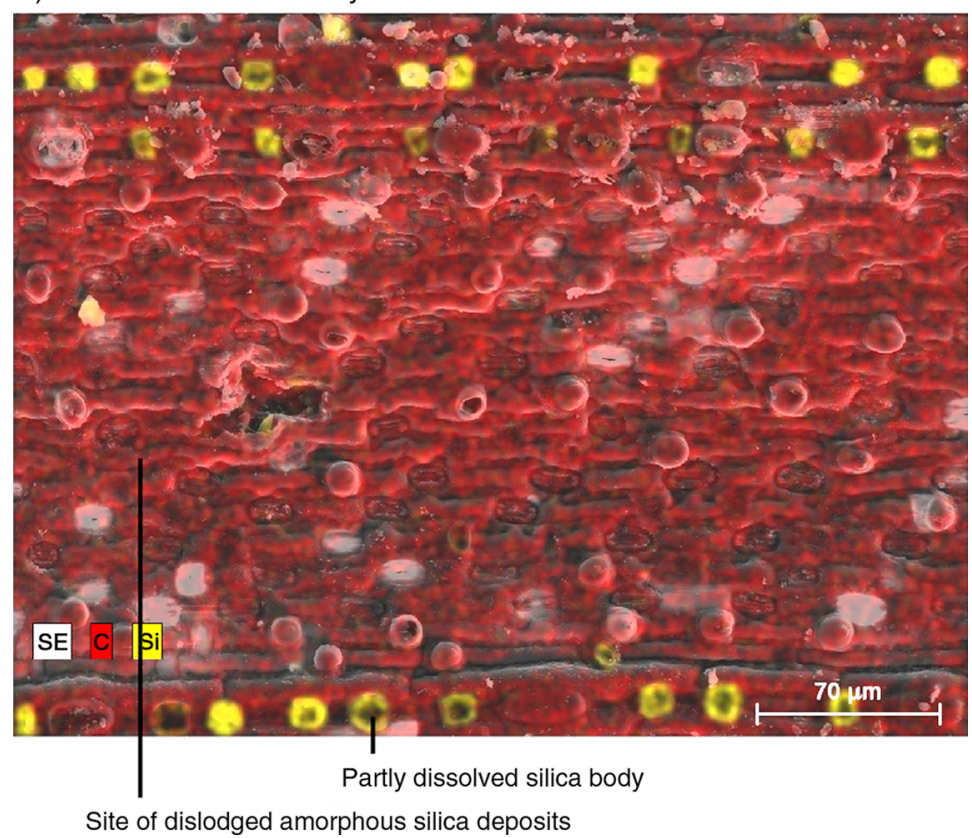

FIG. 2. False-color scanning electron microscopy (SE) images showing the distribution of silica bodies and copious amorphous silica deposits in and on the uppermost surface layer of leaf blades of $P$. australis plants receiving a high dose of Si (46.6 g per 10-L bucket) during plant growth (Si-100) (a) before and (b) after four months of litter decomposition (early December to early April) in unenclosed control plots in a freshwater marsh. Silica appears in yellow, carbon in red. Magnification $350 \times$.

consistent across all treatments in enclosures, including the unenclosed control plots. Furthermore, ergosterol in leaf litter was strongly affected $(P<0.001)$ by $\mathrm{N}$ addition during decomposition (Fig. 3), with concentrations consistently lowered across all Si treatments, again by about $50 \%$. Warming, in contrast, had no effect on ergosterol concentration, nor were there significant interactive effects between Si supply of plants, nitrogen enrichment and warming (Table A1). The highest ergosterol concentrations were observed in the unenclosed control plot, indicating a negative enclosure effect on ergosterol concentration in the decomposing litter.

\section{Litter mass loss}

The influence of global-change factors on litter mass loss varied depending upon the plant tissue considered: 
leaf blades and sheaths responded similarly, whereas mass loss of culms followed a different response pattern (Fig. 4). Specifically, experimental warming increased the mass loss of $P$. australis litter for leaf blades $(P=$ $0.001)$ and sheaths $(P=0.023)$, in spite of notable variability among replicates for most of the warming treatments (Fig. 4a, b). In contrast, $\mathrm{N}$ addition had no significant effects on the mass loss of either tissue (Fig. $4 \mathrm{a}, \mathrm{b})$. Furthermore, elevated Si supply during plant growth resulted in consistently faster decomposition of leaf sheaths $(P=0.017)$, although for leaf blades the same effect was only observed within the lake control treatment $(P=0.016$ for the Si effect in unenclosed plots vs. $P=0.41$ in enclosures). Culm litter decomposition, in contrast to that of leaf blades and sheaths, was not influenced by either warming $(P=0.19)$ or Si supply during plant growth $(P=0.69)$, but instead was affected by $\mathrm{N}$ addition $(P<0.001)$, which slowed the mass loss of culms by about $25 \%$ (Fig. 4c). No interactive effects on litter mass loss were observed for any of the three plant tissues (Table A2). Enclosures had a negative effect on the decomposition of leaf blades $(P<0.001)$ and culms $(P<0.005)$, resulting in slower mass loss in the enclosed control plots compared to the unenclosed controls (Fig. 4a, c).

\section{DiscusSION}

Environmental heterogeneity caused by variation in $\mathrm{Si}$ availability clearly affected litter chemistry $(\mathrm{C}$ and $\mathrm{P}$ concentration) and fungal decomposers, whereas the effects of warming and $\mathrm{N}$ supply on litter decomposition proved to be more complex. In particular, increased $\mathrm{Si}$ in leaf blades approximately halved fungal biomass accrual during decomposition, but this $\mathrm{Si}$ effect did not correspond with the patterns observed for litter mass loss. The resulting uncoupling of fungal growth and decomposition indicates that microbes other than fungi assumed an important role in the decomposition process. Bacteria are prime candidates as alternative decomposers, especially in view of their high productivity on submerged litter (Buesing and Gessner 2006) and the gradual declines of fungal biomass when decomposition of submerged litter proceeds in marshes (Kuehn et al. 2000, Van Ryckegem et al. 2007). This suggests that silica may influence decomposition by altering the composition and relative importance of particular groups of microbial decomposers.

The influence of Si on decomposition depended upon litter tissue type. Specifically, only sheath decomposition was accelerated (Fig. 4). This has also been observed in another study (Schaller and Struyf 2013) and might be due to the particularly high accumulation of $\mathrm{Si}$ in sheath tissue (Schaller et al. 2013). However, the stimulation of sheath decomposition is at variance with the common interpretation that elevated $\mathrm{Si}$ concentrations in plants act as a defense mechanism (Fauteux et al. 2005, Massey and Hartley 2009), which should remain functional after plant death (Cornelissen et al. 2004) and hence reduce microbial decomposer activity. A possible explanation for this apparent paradox is that high $\mathrm{Si}$ concentrations shift the outcome of competitive interactions between fungi and bacteria (Mille-Lindblom and Tranvik 2003) in favor of the latter (Wainwright et al. 1997, Tian et al. 2012). Such a shift could be facilitated by an increase in the surface area of litter available for bacterial colonization when phytoliths and amorphous silica deposits are partially solubilized or mechanically removed during decomposition (Fig. 2; also see Holstein and Hensen 2010). Such a surface area effect could also explain the lacking influence of $\mathrm{Si}$ on the mass loss of leaf blades and culms, because silicon contents and condensation state of these litter types are lower than in sheaths (Schaller et al. 2013). Importantly, fungi are unlikely to benefit in similar ways from surface-area enlargements, because their hyphae penetrate the litter surface to expand their mycelial network within the decomposing plant tissue (Newell et al. 1996).

Temperature increases affected the three litter types (leaf blades, sheaths, and culms) differentially, suggesting that differences in plant tissue chemistry of $P$. australis not only influence decomposition in current conditions, but also determine sensitivity to climate warming. Leaf-blade decomposition, which was the fastest of the three tissues, was accelerated by warming. Leaf sheaths, which on average lost $10 \%$ less mass than leaf blades, responded less strongly to warming but instead lost mass significantly faster at elevated Si supply levels (see above). This contrasts again with culm litter, which responded neither to warming nor to litter Si content. Thus, tissue specific differences in litter chemistry as well as plasticity in the ability to accumulate Si clearly influence decomposition responses to changing environmental conditions.

That temperature effects on litter mass loss arose only for leaf blades and sheaths could in part be due to the much faster decomposition of these tissues compared to that of culm litter, resulting in $40-50 \%$ mass loss of leaf blades within four months at the low winter temperatures. Increased $\mathrm{N}$ immobilization in this condition (Fig. 1b), which suggests enhanced microbial activity, further supports this interpretation. The additional heat input applied by our warming treatment during winter was much more important, in relative terms, than the experimental extra warming experienced by culm litter exposed to the full seasonal cycle (12 months) during which temperatures exceeded $20^{\circ} \mathrm{C}$ for many months. This suggests that climate warming effects could be more pronounced during winter (Easterling et al. 2000, Raisanen et al. 2004). That is, the divergence in the response of different litter types to warming may only emerge when litter decomposes rapidly enough to achieve substantial mass loss during the cold winter months. Although this interpretation only holds if decomposer activity declines, or at least slows, at the elevated temperatures prevailing in summer, evidence from microbial decomposers in streams (Suberkropp 


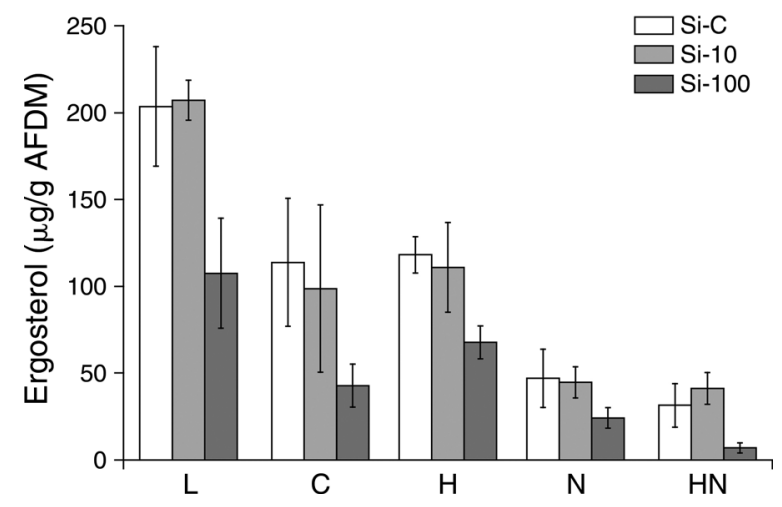

FIG. 3. Ergosterol concentrations (means $\pm \mathrm{SD}, n=4$ replicates) in $P$. australis leaf blades after four months of decomposition (early December to early April) in different environmental conditions. Treatments and abbreviations are as in Fig. 1.

1984, Dang et al. 2009) suggests that this is not an unrealistic assumption.

Similar to effects of $\mathrm{Si}$, increased external $\mathrm{N}$ supply had a strong influence on fungi that did not directly correspond to changes in litter mass loss. Indeed, fungal biomass in leaf blades subjected to high $\mathrm{Si}$ and $\mathrm{N}$ in combination was consistently reduced to only about $25 \%$ of the fungal biomass found on leaf blades in control enclosures, a perfect additive effect on a relative scale. This finding that synergistic or antagonistic effects of multiple environmental drivers do not necessarily complicate projected impacts of microbial decomposers on plant litter is encouraging. It suggests that realistic large-scale models of future litter decomposition and related processes remain within reach. However, mixed responses among tissue types and process rates demonstrate that increased attention needs to be directed to the impacts of environmental heterogeneity on plant tissue quality as a key factor affecting variation in decomposition and associated processes.

As with other effects, the mixed responses of decomposition to $\mathrm{N}$ supply shown by leaf blades and sheaths (i.e., no response) vs. culm litter (negative response) could be explained by differences in litter quality. In forest soils, recalcitrant or partly degraded litter is often inhibited by experimental $\mathrm{N}$ supply, contrasting with stimulated decomposition rates of fresh litter that is relatively labile (Hobbie et al. 2012). Accordingly, N supply significantly slowed the decomposition of recalcitrant culm litter in our experiment, whereas that of rapidly decomposing leaf blades and sheaths (Gessner 2000) was unaffected. Thus, nitrogen effects were prominent on the tissue that decomposed the slowest, contrasting with warming effects that were most pronounced on the fastest decomposing tissue. The mechanism underlying the divergence between litter types in their response to external $\mathrm{N}$ supply remains uncertain, but because bacteria often become more important as litter becomes more refractory with decomposition progressing (Gessner et al. 2007), it could be that $\mathrm{N}$ addition limited bacterial activity. Evidence from forests suggests that $\mathrm{N}$ can inhibit fungal oxidative enzymes (peroxidases) essential for the degradation of lignin, a highly refractory compound that accounts for a large fraction of recalcitrant litter (Carreiro et al. 2000). Although effective lignin-degrading fungi are less common in fresh waters than in forests (Gulis et al. 2006), the same mechanism could work for ligninolytic enzymes of aquatic bacteria (Vicuna 1988, Bugg et al. 2011), and it would also be in line with the $50 \%$ decline in fungal
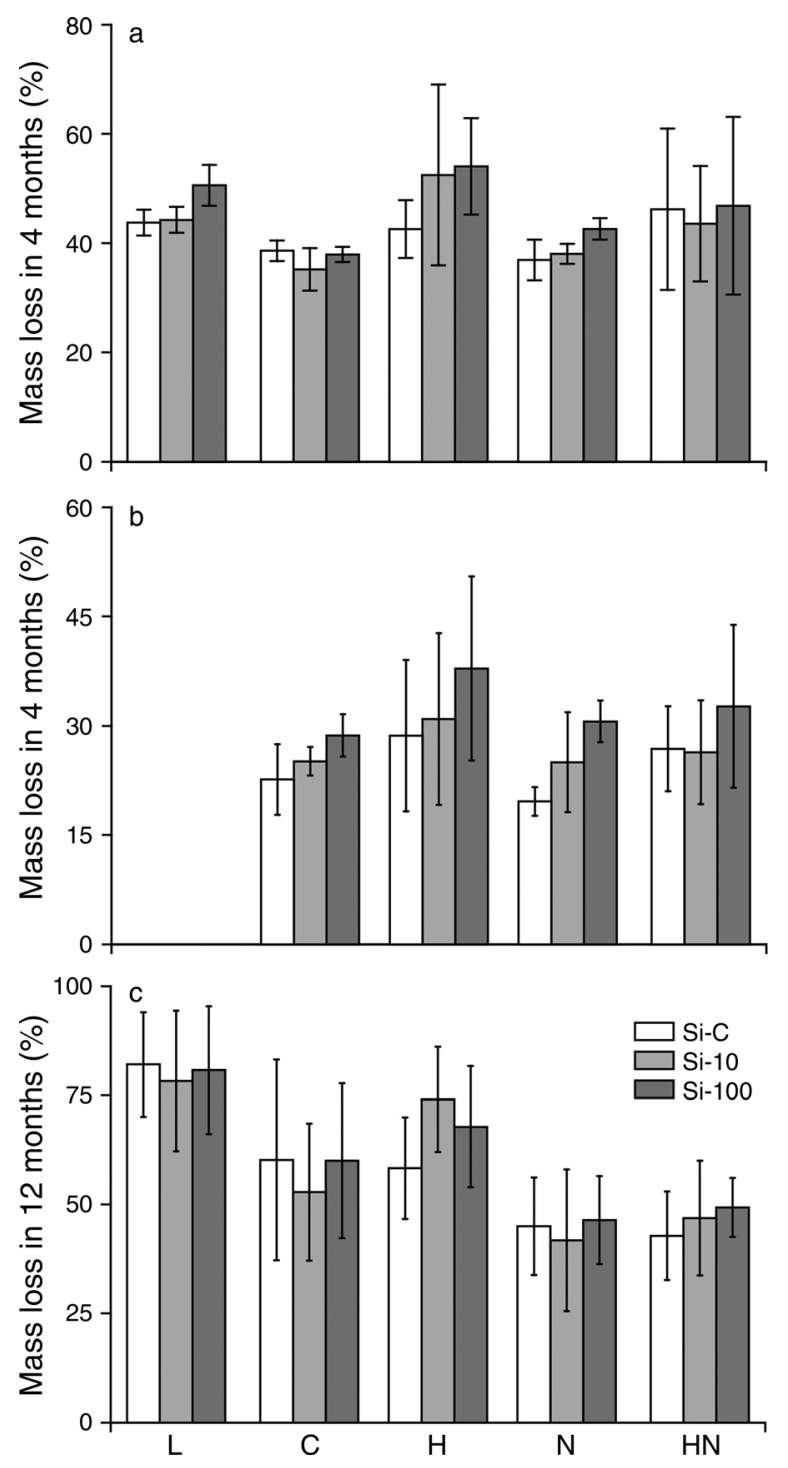

FIG. 4. Loss in ash-free dry mass (AFDM; means $\pm \mathrm{SD}, n=$ 4 replicates) of (a) leaf blade, (b) leaf sheath, and (c) culm litter of Phragmites australis. Plants had been grown at three different silicon supply levels and decomposed in submerged litter bags for 4 months (129 days, from early December to early April, for leaf blades and sheaths) or 12 months (365 days, from early December to early December, for culms). Treatments and abbreviations are as in Fig. 1. 
biomass that we observed when excess $\mathrm{N}$ was supplied to decomposing leaf blades (Fig. 3).

In conclusion, important outcomes of our experiment are that (1) $\mathrm{Si}$ availability during plant growth strongly impacts fungal decomposers, (2) high external $\mathrm{N}$ supply produces equally strong negative effects on fungi, but (3) these negative impacts of $\mathrm{Si}$ and $\mathrm{N}$ on fungi do not invariably translate to slowed decomposition. This could suggest that bacteria in freshwater marshes play a greater role in the decomposition of submerged litter than is commonly recognized. In addition, (4) differences in plant tissue quality within individual species, exaggerated by environmental heterogeneity such as $\mathrm{Si}$ availability, can influence impacts of global change on decomposition. These effects could be particularly pronounced in light of human alteration in the biological availability of multiple chemical elements such as nitrogen (Galloway et al. 2008) and silicon (Struyf and Conley 2009, Vandevenne et al. 2012).

\section{ACKNOWLEDGMENTS}

We thank M. Brosed, M. Doering, R. Illi, and the AUA lab, S. Käppeli, M. Reyes, D. Steiner, N. Tschopp, and others at Eawag's Department of Aquatic Ecology for lab and field assistance during this study; A. Weiske at the Institute of General Ecology and Environmental Protection of TU Dresden for carbon and nitrogen analyses; R. Schulze at the Institute of Bioanalytical Chemistry, TU Dresden, for ICP-OES measurements, and the Department of Civil Engineering, Transportation and Environment of the Canton of Argovia for permission to work at the field site in Switzerland. Funding from the Swiss National Science Foundation (SNF, grant 3100A0-108441) to support the field study in Lake Hallwil is gratefully acknowledged.

\section{Literature Cited}

Adrian, R., et al. 2009. Lakes as sentinels of climate change. Limnology and Oceanography 54:2283-2297.

Blunden, J., D. S. Arndt, and M. O. Baringer. 2011. State of the climate in 2010. Bulletin of the American Meteorological Society 92:1-236.

Buesing, N., and M. O. Gessner. 2006. Benthic bacterial and fungal productivity and carbon turnover in a freshwater marsh. Applied and Environmental Microbiology 72:596605.

Bugg, T. D. H., M. Ahmad, E. M. Hardiman, and R. Singh. 2011. The emerging role for bacteria in lignin degradation and bio-product formation. Current Opinion in Biotechnology 22:394-400.

Carreiro, M. M., R. L. Sinsabaugh, D. A. Repert, and D. F. Parkhurst. 2000. Microbial enzyme shifts explain litter decay responses to simulated nitrogen deposition. Ecology 81:23592365.

Casey, W. H., S. D. Kinrade, C. T. G. Knight, D. W. Rains, and E. Epstein. 2004. Aqueous silicate complexes in wheat, Triticum aestivum L. Plant Cell and Environment 27:51-54.

Cornelis, J. T., B. Delvaux, D. Cardinal, L. Andre, J. Ranger, and S. Opfergelt. 2010. Tracing mechanisms controlling the release of dissolved silicon in forest soil solutions using $\mathrm{Si}$ isotopes and $\mathrm{Ge} / \mathrm{Si}$ ratios. Geochimica et Cosmochimica Acta 74:3913-3924.

Cornelissen, J. H. C., H. M. Quested, D. Gwynn-Jones, R. S. P. Van Logtestijn, M. A. H. De Beus, A. Kondratchuk, T. V. Callaghan, and R. Aerts. 2004. Leaf digestibility and litter decomposability are related in a wide range of subarctic plant species and types. Functional Ecology 18:779-786.
Dang, C. K., M. Schindler, E. Chauvet, and M. O. Gessner. 2009. Temperature oscillation coupled with fungal community shifts can modulate warming effects on litter decomposition. Ecology 90:122-131.

Deutsches Institut für Normung. 1995. DIN-ISO-10694. Soil quality - determination of organic and total carbon after dry combustion (elementary analysis) (ISO 10694:1995). Deutsches Institut für Normung, Berlin, Germany.

Deutsches Institut für Normung. 2002. DIN-EN-13805. Lebensmittel-Bestimmung von Elementspuren-Druckaufschluss. Deutsches Institut für Normung, Berlin, Germany.

Easterling, D. R., G. A. Meehl, C. Parmesan, S. A. Changnon, T. R. Karl, and L. O. Mearns. 2000. Climate extremes: observations, modeling, and impacts. Science 289:2068-2074.

Elser, J. J., T. Andersen, J. S. Baron, A. K. Bergstrom, M. Jansson, M. Kyle, K. R. Nydick, L. Steger, and D. O. Hessen. 2009. Shifts in lake N:P stoichiometry and nutrient limitation driven by atmospheric nitrogen deposition. Science 326:835-837.

Fauteux, F., W. Remus-Borel, J. G. Menzies, and R. R. Belanger. 2005. Silicon and plant disease resistance against pathogenic fungi. Fems Microbiology Letters 249:1-6.

Galloway, J. N., A. R. Townsend, J. W. Erisman, M. Bekunda, Z. C. Cai, J. R. Freney, L. A. Martinelli, S. P. Seitzinger, and M. A. Sutton. 2008. Transformation of the nitrogen cycle: recent trends, questions, and potential solutions. Science 320: 889-892.

Gessner, M. O. 2000. Breakdown and nutrient dynamics of submerged Phragmites shoots in the littoral zone of a temperate hardwater lake. Aquatic Botany 66:9-20.

Gessner, M. O., V. Gulis, K. A. Kuehn, E. Chauvet, and K. Suberkropp. 2007. Fungal decomposers of plant litter in aquatic ecosystems. Pages 301-324 in C. P. Kubicek and I. S. Druzhinina, editors. The Mycota. Volume 4: environmental and microbial relationship. Springer, Berlin, Germany.

Gessner, M. O., and A. L. Schmitt. 1996. Use of solid-phase extraction to determine ergosterol concentrations in plant tissue colonized by fungi. Applied and Environmental Microbiology 62:415-419.

Gulis, V., K. Kuehn, and K. Suberkropp. 2006. The role of fungi in carbon and nitrogen cycles in freshwater ecosystems. Fungi in biogeochemical cycles. Cambridge University Press, Cambridge, UK.

Hines, J., A. Hammrich, D. Steiner, and M. O. Gessner. 2013. A field facility to simulate climate warming and increased nutrient supply in shallow aquatic ecosystems. Oecologia 173:1169-1178.

Hobbie, S. E., W. C. Eddy, C. R. Buyarski, E. C. Adair, M. L. Ogdahl, and P. Weisenhorn. 2012. Response of decomposing litter and its microbial community to multiple forms of nitrogen enrichment. Ecological Monographs 82:389-405.

Holstein, J. M., and C. Hensen. 2010. Microbial mediation of benthic biogenic silica dissolution. Geo-Marine Letters 30: 477-492.

IPCC. 2007. Climate change 2007: the physical science basis. Cambridge University Press, Cambridge, UK.

Jeppesen, E., et al. 2010. Interaction of climate change and eutrophication. Pages 119-151 in M. R. Kernan, R. W. Battarbee, and B. Moss, editors. Climate change impacts on freshwater ecosystems. Wiley-Blackwell, Chichester, UK.

Knorr, M., S. D. Frey, and P. S. Curtis. 2005. Nitrogen additions and litter decomposition: a meta-analysis. Ecology 86:3252-3257.

Kuehn, K. A., M. J. Lemke, K. Suberkropp, and R. G. Wetzel. 2000. Microbial biomass and production associated with decaying leaf litter of the emergent macrophyte Juncus effusus. Limnology and Oceanography 45:862-870.

Massey, F. P., and S. E. Hartley. 2009. Physical defences wear you down: progressive and irreversible impacts of silica on insect herbivores. Journal of Animal Ecology 78:281-291. 
McNaughton, S. J., and J. L. Tarrants. 1983. Grass leaf silification-natural-selection for an inducible defence against herbivores. Proceedings of the National Academy of Sciences USA 80:790-791.

McNaughton, S. J., J. L. Tarrants, M. M. McNaughton, and R. H. Davis. 1985. Silica as a defence against herbivory and a growth promoter in African grasses. Ecology 66:528-535.

Mille-Lindblom, C., and L. J. Tranvik. 2003. Antagonism between bacteria and fungi on decomposing aquatic plant litter. Microbial Ecology 45:173-182.

Newell, S. Y., D. Porter, and W. L. Lingle. 1996. Lignocellulolysis by ascomycetes (Fungi) of a saltmarsh grass (smooth cordgrass). Microscopy Research and Technique 33:32-46.

Raisanen, J., U. Hansson, A. Ullerstig, R. Doscher, L. P. Graham, C. Jones, H. E. M. Meier, P. Samuelsson, and U. Willen. 2004. European climate in the late twenty-first century: regional simulations with two driving global models and two forcing scenarios. Climate Dynamics 22:13-31.

Schaller, J., C. Brackhage, and E. Dudel. 2012a. Silicon availability changes structural carbon ratio and phenol content of grasses. Environmental and Experimental Botany 77:283-287.

Schaller, J., C. Brackhage, M. O. Gessner, E. Bäuker, and E. G. Dudel. 2012b. Silicon supply modifies C:N:P stoichiometry and growth of Phragmites australis. Plant Biology 14:392396.

Schaller, J., C. Brackhage, S. Paasch, E. Brunner, E. Bäucker, and E. G. Dudel. 2013. Silica uptake from nanoparticles and silica condensation state in different tissues of Phragmites australis. Science of the Total Environment 442:6-9.

Schaller, J., and E. Struyf. 2013. Silicon controls microbial decay and nutrient release of grass litter during aquatic decomposition. Hydrobiologia 709:201-212.

Soininen, E. M., K. A. Brathen, J. G. H. Jusdado, S. Reidinger, and S. E. Hartley. 2013. More than herbivory: levels of silica- based defences in grasses vary with plant species, genotype and location. Oikos 122:30-41.

Struyf, E., and D. J. Conley. 2009. Silica: an essential nutrient in wetland biogeochemistry. Frontiers in Ecology and the Environment 7:88-94.

Struyf, E., et al. 2010. Historical land use change has lowered terrestrial silica mobilization. Nature Communications 1:129.

Suberkropp, K. 1984. Effect of temperature on seasonal occurrence of aquatic hyphomycetes. Transactions of the British Mycological Society 82:53-62.

Tian, L., X. D. Chen, Q. P. Yang, J. C. Chen, Q. Li, and L. Shi. 2012. Effect of silica dioxide particles on the evolution of biofouling by Bacillus subtilis in plate heat exchangers relevant to a heat pump system used with treated sewage. Chemical Engineering Journal 188:47-56.

Van Ryckegem, G., M. O. Gessner, and A. Verbeken. 2007. Fungi on leaf blades of Phragmites australis in a brackish tidal marsh: diversity, succession, and leaf decomposition. Microbial Ecology 53:600-611.

Vandevenne, F., E. Struyf, W. Clymans, and P. Meire. 2012. Agricultural silica harvest: have humans created a new loop in the global silica cycle? Frontiers in Ecology and the Environment 10:243-248.

Vicuna, R. 1988. Bacterial-degradation of lignin. Enzyme and Microbial Technology 10:646-655.

Vörösmarty, C. J., et al. 2010. Global threats to human water security and river biodiversity. Nature 467:555-561.

Wainwright, M., K. AlWajeeh, and S. J. Grayston. 1997. Effect of silicic acid and other silicon compounds on fungal growth in oligotrophic and nutrient-rich media. Mycological Research 101:933-938.

Zimmermann, F., M. Opfermann, E. Bäucker, J. Fiebig, and W. Nebe. 2000. Nutrition-physiological responses of spruce to different levels of sulphur dioxide stress in the Erzgebirge Mountains and the Thuringian Forest, Germany. Forstwissenschaftliches Centralblatt 119:193-207.

\section{SupPlemental Material}

\section{Ecological Archives}

The Appendix is available online: http://dx.doi.org/10.1890/13-2104.1.sm 